\title{
The Roles of Mass Media in Disseminating Agricultural Information to Farmers in Birnin Kebbi Local Government Area Of Kebbi State: A Case Study of State Fadama II Development Project
}

\author{
Abubakar, B. Z., Ango, A. K., Buhari, U. \\ Department of Agricultural Economics and Extension \\ Usmanu Danfodiyo University, Sokoto \\ E-Mail: aakamba2@yahoo.com
}

\begin{abstract}
The study examined the roles of mass media in disseminating agricultural information to farmers in Birnin Kebbi Local Government Area. Eighty (80) structured questionnaires were randomly administered to selected respondents from five districts participating in the State Fadama II Development activities in the study area. Data collected were analyzed using both descriptive and inferential statistics. The studies revealed that majority of the respondents are full time farmers and are having personal lands with more than twenty one (21) years of farming experience. The study further shows that access to mass media on agricultural information is through radio and television, and most of them indicated that the media sources are conventional, accessible and preferred to listen to the agricultural progammes in the night time (8pm -11.59pm). The respondents identified purchasing and maintenance of media source (television and radio) as their major problems. The hypotheses tested showed a significant relationship between farmer's sources of agricultural information and relevance of information received in solving agricultural problems $(r=0.544, p=0.290)$. Finally, it is recommended that more efforts should be intensified in providing more agricultural information to farmers through radio and televisions most especially during night time and local community viewing centres should be established by the government.
\end{abstract}

Keywords: Mass Media, Dissemination. Agricultural information, fadama farmers, Kebbi State.

\section{INTRODUCTION}

In spite of growing urbanization and increased revenue from the oil sector, agriculture is still the mainstay of the Nigerian economy. Historical experiences have shown that there are no cases of successful development of a major country in which the rise in agricultural productivity did not precede or accompany development (Audu, 2003).

Adams (1982) defined media as any materials, objects, instruments or system which serves to communicate information including leaflets, farming press, other written and printed materials, all types of cinema films, radio and television and video system. Communication has also been defined as a process by which participants create and share information with one 
another in order to reach mutual understanding. He further defined communication as a process of sending and receiving messages through the channels and devices at a convergence and as established meaning between a source and receiver (Rogers, 1995).

Effective communication of new research findings and technologies in agriculture to rural farmers remains a promising strategy for increasing agricultural productivity. Generally, such information may include techniques of applying fertilizers, insecticides and fungicides to crops, improved methods of cultivation and soil conservation, techniques of planting, harvesting and storage of crops. There are also new technologies of animal husbandry as well as processing and marketing of various agricultural products. For the farmers to adopt the new technologies and put them to use, the new idea must reach their farms and homes through effective extension communication methods such as mass media channels. The mass media are increasingly becoming a veritable instrument for transforming Nigerian agriculture through which people will derive pleasure from learning how the food they eat daily is produced and they may be encouraged to develop an interest in growing some food themselves (Patrick, 2001).

This paper therefore intends to examine the roles of mass media in disseminating agricultural information to farmers in the study area.

\section{Statement of the Problem}

The effectiveness of mass media in disseminating agricultural innovations in the study area has never been recognized, despite the fact that researchers are still conducting research on agriculture, and extension workers are still trying to bridge the gap between the research stations and rural farmers. This has consequently marginalized agriculture and farming family which resulted to low productivity in spite of the efforts of the mass media in communicating agricultural information to the farmers.

This research therefore, attempts to address some of the following research questions:

1. Do socio-economic characteristics of the farmers have any influence on the sources of information through mass media?

2. What are the available mass media that have been used to communicate extension delivery services to the farmers of Fadama Development Project?

3. To which extent are these sources relevant to then fadama farmers?

4. What are the problems the fadama farmers face in accessing the mass media sources?

\section{Objectives of the Study}

The major objective of the study is to examine the roles of mass media in disseminating agricultural information to fadama farmers in the area under study, while the specific objectives are to:-

(i) identify the socio-economic characteristic of the farmers.

(ii) determine the agricultural enterprise of the farmers.

(iii) determine the farmer's accessibility to mass media and its associate problems.

(iv) determine the farmer's problems and relevance of the mass media in disseminating agricultural technology 
Journal of Agricultural Extension

Vol. 13 (2) December 2009

\section{Hypotheses}

(i) There is no significant relationship between farmer's sources of agricultural information and their socio-economic characteristics.

(ii) There is no significant relationship between farmer's sources of agricultural information and their level of agricultural production.

(iii) There is no significant relationship between farmer's sources of agricultural information and relevance of information in solving agricultural problems.

\section{METHODOLOGY}

\section{Study area}

The study on roles of mass media in dissemination of agricultural information was carried out in Birnin Kebbi Local Government Area (LGA). The study area lies at an altitude of $200 \mathrm{~m}$, latitude $12^{\circ} 32^{\prime} \mathrm{N}$ and longitude of $4^{0} 12^{\prime} \mathrm{E}$ in the Sudan Savannah vegetation zone. The majority of the people in the study area are predominantly peasant farmers who engaged in cultivation of various types of crops and rearing of animals.

\section{Sampling procedure \& sample size}

A multistage sampling technique was used to select five districts, and from each district four (4) communities were selected out of which four (4) fadama farmers were randomly sampled from each community, giving a total sample size of eighty (80) respondents.

\section{Data collection methods}

The data for this study were generated through the use of structured questionnaires which were administered with the help of trained enumerators. The questionnaires distributed to the farmers were structured interview schedules and the questions were mostly to cover relevant information about the general socio-economic characteristics of the farmers, such as age, sex, educational level, farm size, marital status; major sources of media available; level of information utilized; farming experience; house hold size, general problems encountered with media usage and relevancy of information sources.

\section{Data analyses}

The data obtained from the administered questionnaires were subjected to descriptive and inferential statistics

\section{RESULTS AND DISCUSSIONS}

\section{Socio - Economic Characteristics of Respondents.}

\section{Age of farmers}

Table 1 reveals that $33.75 \%$ of the respondents are within the age range of $51-60$ years, $28.75 \%, 21.25 \%, 13.75 \%$ and $2.5 \%$ are within $31-40$ years, $41-50$ years, less than 30 years and more than 60 years respectively. The high number of respondents with the ages of 51 years and above can be attributed to the fact that most of the young able bodied persons are in urban areas seeking for white collar and petty jobs. 


\section{Journal of Agricultural Extension \\ Vol. 13 (2) December 2009}

\section{Sex of the farmers}

Table 1 shows that majority (90\%) of the respondents are males, while only $10 \%$ are females. The wide difference in sex between male to female ratio in agricultural activities can be attributed to the fact that the study area is Muslim dominated community, in which women are hardly allowed to be engaged in farming activities. Women in these communities are mostly allowed to take part in backyard farming and rearing of household animals and household chores. This statement was corroborated by Ango (1999) who reported that rural female farmers are not statistically identified as active population, as a result, their productive economic roles are regarded as part of their domestic and reproductive roles.

\section{Family size of farmers}

Table 1 indicates that $36.25 \%$ of the respondents are having between $11-15$ members of household, $26.25 \%$ of the respondents have $1-5$ house members while only $7.5 \%$ of the farmers have more than 20 household members. This finding is in accordance with related of Muntaqha (2007) which revealed that $23.81 \%$ of the respondents from IFAD-CBARDP Sokoto State have between $6-20$ children. The reason behind large family size could be due to polygamous nature of Hausas and their dependency on family as source of farm labour (Ango, 1999).

\section{Educational attainment of farmers}

Table 1 reveals that $100 \%$ of the respondents have attained a certain form of education. More than $50 \%$ of the respondents have attained Qur'anic/lslamic education, $45 \%$ attained formal education (primary \& secondary education), while only $3.75 \%$ attained the adult literacy education. The higher level of education among the farmers in the study area may be attributed to the fact that hardly one can see a person without enrolling in either Qur'anic or western education. 
Journal of Agricultural Extension

Vol. 13 (2) December 2009

TABLE 1: Distribution of respondents according to socio-economic characteristics

Variable $\quad$ Frequency $(\mathrm{n}) \quad$ Percentage (\%)

\begin{tabular}{|c|c|c|}
\hline \multicolumn{3}{|l|}{ Age } \\
\hline Less than 30 years & 11 & 13.75 \\
\hline $31-40$ years & 23 & 28.75 \\
\hline $41-50$ years & 17 & 21.25 \\
\hline $51-60$ years & 27 & 33.75 \\
\hline 61 years and above & 2 & 2.5 \\
\hline \multicolumn{3}{|l|}{ Gender } \\
\hline Male & 72 & 90 \\
\hline Female & 8 & 10 \\
\hline \multicolumn{3}{|l|}{ Marital status } \\
\hline Single & 9 & 11.25 \\
\hline Married & 66 & 82.5 \\
\hline Divorced & 2 & 2.5 \\
\hline Widowed & 3 & 3.75 \\
\hline \multicolumn{3}{|l|}{ Household size } \\
\hline None & 9 & 11.25 \\
\hline $1-5$ family members & 11 & 13.75 \\
\hline $6-10$ family members & 21 & 26.25 \\
\hline 11 - 15 family members & 29 & 36.25 \\
\hline $16-20$ family members & 6 & 7.5 \\
\hline 21 family members and above & 4 & 5 \\
\hline \multicolumn{3}{|l|}{ Educational attainment } \\
\hline Non formal education & 0 & 0 \\
\hline Adult literacy & 3 & 3.75 \\
\hline Qur'an/Islamic Education & 41 & 51.25 \\
\hline Formal & 36 & 45 \\
\hline
\end{tabular}

Source: Field Survey 2008

\section{Agricultural Enterprise of Respondents}

\section{Major occupation of fadama farmers}

Table 2 reveals that $95 \%$ of the respondents are full time farmers, while only $5 \%$ are full time traders but are involved in farming as an income generating activity. The high percentage of full time farming can be attributed to the fact that most of the rural populace in the study area are engaged in one form of farming or the other in order not to remain idle.

\section{Major agricultural enterprise of farmers}

Table 2 reveals that $52.5 \%$ of the respondents are involved in crop based agriculture (maize, millet, sorghum, etc), $40 \%$ of the respondents are into Fadama based agriculture (rice, gardening, sugar cane, etc), while only $7.5 \%$ are found participating in livestock based agriculture (cattle, goats, sheep, poultry etc). This attitude of majority of farmers involving in crop based farming leads to the production of more cereal foods than other classes of food 
consumed in the sub-Saharan Africa. CBN Report (1990) also indicated crop production as the major agricultural enterprise farmers are engaged in. Being peasants, the farmers normally consume and sell some of these cereal crop products to purchase what is not produced in the farm.

\section{Land ownership status of farmers}

Table 2 shows that $85 \%$ of the respondents own their land, $13.75 \%$ of the respondents are using family land, while only $1.25 \%$ of the respondents are using hired land for agricultural production. This can be attributed to the fact that land inheritance exists in the communities thereby enabling farmers to inherit land from their predecessors. This study is corroborated by Ango (1999) who posits that inheritance is the common mode of acquiring land and this is based on strict Shari'a law practiced in the study area, where the land of any deceased person is normally passed on to his/her heirs. Through this process, every member of the community may get at least a portion of land from his ancestors. The Shari'a law has undermined the customary principles which emphasized collective ownership of land. It also established rules concerning transfer, inheritance of land and commercial transactions of land.

\section{Agricultural land size (ha) of farmers}

Table 2 indicates that $52.5 \%$ of the respondents are operating on large scale with land of over 5 ha while $47.5 \%$ of the respondents are operating on land of 5 ha and below and $32.5 \%$ operates on medium scale (3-4ha) and $15 \%$ on small scale (1-3ha).

\section{Farming experience of farmers}

Table 2 reveals that $70 \%$ of the respondents are having 21 years and above of farming experience, and $20 \%$ of the respondents are having $16-20$ years of farming experience while only $1.25 \%$ of the farmers are having farming experience of $1-5$ years. The long years of farming experience among the farmers may be due to the fact that the farmers in the study area have no recognized business apart from farming.

\section{Type (variety) of crop grown by farmers}

Table 2 reveals that $77.5 \%$ of the respondents use local variety of seeds for farming, while $22.5 \%$ respondents use improved varieties. The use of improved varieties by majority of farmers is attributed to the efforts of the media and the extension agents in the area. 
Journal of Agricultural Extension

Vol. 13 (2) December 2009

TABLE 2: Distribution of respondents according to agricultural enterprise

\begin{tabular}{|c|c|c|}
\hline Variable & Frequency (n) & Percentage (\%) \\
\hline \multicolumn{3}{|l|}{ Major occupation } \\
\hline Farming & 76 & 95 \\
\hline Trading & 4 & 5 \\
\hline Carpentry & 0 & 0 \\
\hline Civil servant & 0 & 0 \\
\hline Others & 00 & 00 \\
\hline \multicolumn{3}{|c|}{ Major agricultural enterprise } \\
\hline Crop base & 42 & 52.5 \\
\hline Livestock Based & 6 & 7.5 \\
\hline Fishery based & 0 & 0 \\
\hline Forestry Based & 0 & 0 \\
\hline Fadama based & 32 & 40 \\
\hline Fruits based & 0 & 0 \\
\hline \multicolumn{3}{|l|}{ Land ownership status } \\
\hline Personal Land & 68 & 85 \\
\hline Land tenant & 1 & 1.25 \\
\hline Family land & 11 & 13.75 \\
\hline Community land & 0 & 0 \\
\hline \multicolumn{3}{|l|}{ Agricultural land size (ha) } \\
\hline Small Scale $(0.1-2.5)$ & 12 & 15 \\
\hline Medium Scale $(2.6-5)$ & 26 & 32.5 \\
\hline Large Scale $(\geq 5.1)$ & 42 & 52.5 \\
\hline \multicolumn{3}{|l|}{ Farming experience } \\
\hline$\leq 1$ year & 0 & 0 \\
\hline $2-5$ years & 1 & 1.25 \\
\hline $6-10$ years & 3 & 3.75 \\
\hline $11-15$ years & 4 & 5 \\
\hline $16-20$ years & 16 & 20 \\
\hline$\geq 21$ years & 56 & 70 \\
\hline \multicolumn{3}{|l|}{ Type of crop grown } \\
\hline Improved variety & 18 & 22.5 \\
\hline Local variety & 62 & 77.5 \\
\hline \multicolumn{3}{|l|}{ Types of animals kept } \\
\hline Cattle & 41 & 51.25 \\
\hline Sheep & 19 & 23.75 \\
\hline Goats & 14 & 17.5 \\
\hline Pigs & 0 & 0 \\
\hline Birds & 6 & 7.5 \\
\hline
\end{tabular}

Source: Field Survey 2008 


\section{Access to Mass Media Information}

\section{Farmers' sources of agricultural information}

Table 3 indicates that majority $(85 \%)$ of the respondents receive their agricultural information from radio and television and $8.75 \%$ of the respondents receive their agricultural information from extension bulletins, while $6.25 \%$ of the respondents got agricultural information from posters.

\section{The conventionality of media sources to farmers}

Table 3 shows that $77.5 \%$ of the respondents identified their media sources as highly conventional, $15 \%$ of the respondents identified their media sources as moderately conventional, while only $7.5 \%$ respondents identified their media sources as not conventional. Exposure to conventional sources of information accelerates the adoption process of new agricultural innovation by farmers because people are made to be aware of potential benefits associated with adopting new agricultural technology which is as a function of the extension personnel employing appropriate communication techniques in communicating with the farmers (Mantau, 1998).

\section{Accessibility of media sources to farmers}

Table 3 reveals that $76.25 \%$ of the respondents identified their media sources as highly accessible, $13.75 \%$ of the respondents identified their media sources as moderately accessible; while only $10 \%$ of the respondents identified the media sources as not accessible to them. This finding is based on Nwachukwu (2003) who pointed that the introduction of radio has been longer than any other mass medium, hence; almost every household has a radio set. The use of local languages and dialects is also more, especially in radio than any other channel. Radio is known to be the most effective mass media channel for communicating agricultural information. So also the television, as it has become part of our national life, if properly used, it may be an effective channel for communicating agricultural innovations and information.

\section{Preferred time of listening to agricultural programmes by farmers}

Table 3 indicates that majority $(65 \%)$ of the respondents identified night time as their preferred time of listening to radio and $22.5 \%$ identified afternoon as the their preferred time. Audu (2003) in a related study in Bali Local government Area of Taraba State revealed that $62.5 \%$ of farmers prefer listening to radio and television programmes at night time. Yahaya (2001) further revealed that farmers own functional radio sets and prefer $8-10 \mathrm{pm}$ for listening to agricultural programmes on both radio and television. 
Journal of Agricultural Extension

Vol. 13 (2) December 2009

TABLE 3: Distribution of respondents according to utilization of media source

\begin{tabular}{lcc}
\hline Variable & Frequency (n) & Percentage (\%) \\
\hline Sources of agricultural & & \\
information & 68 & 85 \\
Radio \& Television & 0 & 0 \\
Newspapers & 7 & 8.75 \\
Extension Bulletin & 5 & 6.25 \\
Poster & & \\
Conventionality of the & 62 & 77.5 \\
source(s) of media & 12 & 15 \\
Highly conventional & 6 & 7.5 \\
Moderately conventional & & \\
Not conventional & 61 & 76.25 \\
Accessibility of the media & 11 & 13.75 \\
source(s) & 8 & 10 \\
Highly accessible & & \\
Moderately accessible & 18 & 22.5 \\
Not accessible & 2 & 2.5 \\
Preferred time of listening to & 8 & 10 \\
agricultural programme & 52 & 65 \\
Morning (5am - 11.59am) & & \\
Afternoon (12noon - 4pm) & & \\
Evening (4pm - 7.59pm) & & \\
Night (8pm - 11.59pm) & & \\
\hline
\end{tabular}

Source: Field Survey 2008

Relevance of information received in solving farmer's agricultural production.

Table 4 shows that $65 \%$ of the respondents identified high relevancy of the information, $27.5 \%$ agreed that the source of information is moderately relevant and only $7.5 \%$ of the farmers says its not relevant. This findings is in corroboration with Muntaqha (2007) who revealed that $67.86 \%$ of the respondents are satisfied with the information received from the sources of mass media from IFAD-CBARDP of Sokoto State.

\section{Importance of information received in solving farmer's agricultural problems}

Table 4 reveals that $100 \%$ of the fadama farmers have received one form of solution or the other to their agricultural problems through the mass media. It further shows that $52.5 \%$ of the respondents identified, infrastructural problems, rivers desilting, construction of veterinary clinics, construction of cold rooms, construction of fish ponds, construction of feeder roads and culverts, construction of latrine toilets, drainage systems as a solution to their problems; $22.5 \%$ of the respondents identified mass media as a solution to asset acquisition (threshing machines, grinding machines, animals for fattening, water pumps, cattle drinking trough); $13.75 \%$ of the respondents identified mass media as a solution on capacity building (trainings, sensitizations). However, $11.25 \%$ of the respondents identified inability to access support from the project (due to inability to meet the financial requirements of $10 \%$ counter-part contribution needed to access the support). 


\section{Problems encountered in obtaining information from the media source}

Table 4 reveals that $35 \%$ of the respondents identified high cost of purchasing and maintaining media source (battery, television, radio), $20 \%$ identified inability to respond to media immediately, $20 \%$ identified power failure, $13.75 \%$ identified no problem, while $11.25 \%$ identified poor signal as problems/constraints with the information received from the media sources. Muntaqha (2007) in a related study revealed that $47.62 \%, 17.86 \%$ and $15.48 \%$ to be the problems/constraints in obtaining information from media source according to poor airtime of programme, high cost of electronics and lack of electricity (power) respectively. Audu (2003) also revealed that $44.46 \%, 16.07 \%$ and $8.93 \%$ to be the problems/constraints in obtaining information from media source according to high cost of purchasing media source, language barriers and power failure respectively in Bali Local Government of Taraba State.

TABLE 4: Distribution of respondents according to relevance and problems of the media sources

\begin{tabular}{lcc}
\hline Variable & Frequency (n) & Percentage (\%) \\
\hline $\begin{array}{l}\text { Relevancy of information received in solving } \\
\text { agricultural problems }\end{array}$ & 52 & 65 \\
Highly relevant & 22 & 27.5 \\
Moderately relevant & 6 & 7.5 \\
Not relevant & & \\
Relevancy of information received in & & 90 \\
improving agricultural production & 72 & 10 \\
Yes & 8 & \\
No & & 13.75 \\
Solving of agricultural problems from & 11 & 52.5 \\
information received & 42 & 22.5 \\
Capacity building & 18 & 11.25 \\
Infrastructural development & 9 & 0 \\
Pilot asset acquisition & 0 & \\
Inability to access support & & 13.75 \\
Inability to implement support received & & 0 \\
Problems encountered in obtaining & & 11.25 \\
information from the media source & 11 & 20 \\
No problem/constraint & 0 & 35 \\
Language barriers & 9 & 20 \\
Poor signal & 16 & \\
Inability to respond immediately to source & & \\
High cost of purchasing \& maintaining media & 28 & \\
source & 16 & \\
Power failure & & \\
Pon & & \\
\hline
\end{tabular}

Source: Field Survey 2008 
Journal of Agricultural Extension

Vol. 13 (2) December 2009

\section{Tests of Hypotheses}

The following hypotheses were derived and Pearson correlation matrix is used in determining the relationships.

Table 5 reveals that socio-economic characteristics and type of agricultural enterprise of farmers in the study area are negatively correlated $(r=-0.010, p=0.956)$; it therefore; indicates that there is no significant relationship between socio-economic characteristics and type of agricultural enterprise of farmers at $5 \%$ level of significance. Therefore, the null hypothesis is hereby accepted. This implies that farmers socio- economic characteristics is not related with source of information received.

Table 5 also shows that agricultural enterprise and sources of agricultural information of farmers in the study area are positively correlated $(r=0.071, p=0.795)$. Here also, the relationship is not significant at $5 \%$ level of significance. Therefore, the null hypothesis is accepted .This also implies that the farmers agricultural enterprise is not related with their source of information.

Table 5 further indicates that the sources of agricultural information and relevance of the information received in solving agricultural problems of farmers in the study area are positively correlated $(r=0.544, p=0.029)$ at $5 \%$ level of significance. Therefore, the null hypothesis is rejected. The result implies that the more information the farmers receive, the more the information is utilized in solving their agricultural problems.

TABLE 5: Test of hypotheses

\begin{tabular}{llllll}
\hline S/No. & Variable & r-value & df & p-value & Remark \\
\hline 1 & $\begin{array}{l}\text { Socio economic characteristics and agricultural } \\
\text { enterprise }\end{array}$ & -0.10 & 33 & 0.956 & NS \\
2 & $\begin{array}{l}\text { Agricultural enterprise and sources of } \\
\text { agricultural information }\end{array}$ & 0.071 & 16 & 0.795 & NS \\
3 & $\begin{array}{l}\text { Sources of agricultural information and } \\
\text { relevance of information received in solving } \\
\text { farmers problems }\end{array}$ & $0.544^{*}$ & 16 & 0.290 & $\mathrm{~S}$ \\
\hline
\end{tabular}

* Correlation is significant at 0.05 levels (2-tailed)

NS... Not significant

S....Significant 


\section{CONCLUSION}

From the study conducted, it has been observed that mass media is an efficient modern means of communication which possesses peculiar quality of sound, pictures and practical method of demonstrations; it also serves as an important source of farm information dissemination medium to the farmers. It has also been concluded that mass media is considered as a source of information to the rural populace and has become an important communicating tool to the farmers in the rural areas. Despite the importance of these media, they are still not within the financial reach of the farmers in terms of purchase and continuous maintenance, e.g. power problem, cost of purchase of the medium, cost of battery, maintenance of the medium, cost of using generator and unavailability of national power in the study area.

It has been observed that almost all the farmers usually receive information on agriculture from mass media sources most especially radio and television stations, and most of the farmers agreed that the media sources are highly accessible. It is therefore, concluded that the information disseminated through the mass media is highly relevant and was utilized in solving problems of the farmers.

\section{REFERENCES}

Adams M.E. (1982). Agricultural Extension in Developing Countries. London Longman Group Limited pp. 37-39

Akangbe, J.A. \& Ojetayo, M.A. (2005). "Socio economic factors affecting bee hunting activities in Oke-Ogun area, Oyo State, Nigeria". Oludimu, F. (ed.): Journal of Agricultural Management and Rural Development vol(2) pp1-30

Ango, A.K. (1999). "Comparative analysis of the impact of Bakolori Irrigation Project and Fadama Development Programme of Sokoto/Kebbi watershed”. M.Sc. Thesis, University of Ibadan.p54

Audu, Z.I. (2003). "The sources of mass media in disseminating agricultural information to farmers in Taraba State (A case study of Bali Local Government Area)". Post graduate diploma research project. Abubakar Tafawa Balewa University( ATBU) Bauchi p25

Baba, K.M.(1998). "Promoting agricultural resource use and farm income through small-scale irrigation: A case study of Sokoto State". Nigerian Journal of Rural Sociology. Special edition Vol. 2 1998. Pp. 21-28

Buhari, U.A. (2005). "Socio-economic determinants of technology adoption by farmers: A case study of Maigana zone of the Kaduna State Agricultural Development Programme". Under graduate research project, Abubakar Tafawa Balewa University( ATBU) Bauchi p53

CBN (1990). "Economic and financial review". 28(2). p.15

Mantau, M.F. (1998). "The role of Bauchi State Agricultural Development Programme ( BSADP) in Agricultural Development. A case study of the Western Zone". Under graduate research project, Abubakar Tafawa Balewa University( ATBU) Bauchi p42

Muntaqha, A.D. (2007). "The role of mass media in agricultural extension service delivery, a case study of IFAD-CBARDP Sokoto". Post graduate diploma research project, Usmanu Danfodiyo University( UDU) Sokoto. pp1-43. 
Journal of Agricultural Extension

Vol. 13 (2) December 2009

Nwachukwu, I. (2003). Agricultural Communication, Principles and Practice. LambHouse Publishers, Umuahia, Nigeria pp1-50

Olaitan S.O. (1979). "The role of Mass Media in Agricultural Education". A paper presented at processing of the first National teaching method workshop, DAC-ABU Zaria

Patrick, E. E. (2001). "Mass Media support for adult education in agriculture in Southern Nigeria". Paper presentation pp. 1-5

Rogers, E.M. (1995). "Communication of innovation”. Nigerian Journal of Agricultural Extension

Umaru, S.G. (2002). "Factors militating the effectiveness of agricultural extension activities (a case study of Birnin Kebbi LGA of Kebbi State)". Post graduate diploma research project, UDU Sokoto

Yahaya, K.M. (2001). "Media pattern of women farmers in northern Nigeria: Imperatives for sustainable and gender sensitive extension delivery". African Crop Science Conference Proceedings 5(1) pp. 747-754 